\title{
Congenital and childhood atrioventricular blocks: pathophysiology and contemporary management
}

\author{
Alban-Elouen Baruteau ${ }^{1,2,3}$ • Robert H. Pass ${ }^{4}$ - Jean-Benoit Thambo ${ }^{2}$ • \\ Albin Behaghel $^{5}$ - Solène Le Pennec ${ }^{5}$ Elodie Perdreau ${ }^{2} \cdot$ Nicolas Combes $^{6}$.

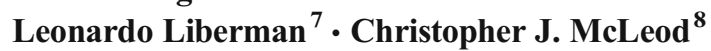

Received: 28 January 2016 /Revised: 13 June 2016 / Accepted: 16 June 2016 / Published online: 28 June 2016

(C) The Author(s) 2016. This article is published with open access at Springerlink.com

\begin{abstract}
Atrioventricular block is classified as congenital if diagnosed in utero, at birth, or within the first month of life. The pathophysiological process is believed to be due to immune-mediated injury of the conduction system, which occurs as a result of transplacental passage of maternal anti-SSA/Ro-SSB/La antibodies. Childhood atrioventricular block is therefore diagnosed
\end{abstract}

between the first month and the 18th year of life. Genetic variants in multiple genes have been described to date in the pathogenesis of inherited progressive cardiac conduction disorders. Indications and techniques of cardiac pacing have also evolved to allow safe permanent cardiac pacing in almost all patients, including those with structural heart abnormalities.
Communicated by Jaan Toelen

\section{Alban-Elouen Baruteau}

alban-elouen.baruteau@u-bordeaux.fr

Robert H. Pass

pediheart@aol.com

Jean-Benoit Thambo

jean-benoit.thambo@chu-bordeaux.fr

Albin Behaghel

albinbehaghel@hotmail.com

Solène Le Pennec

lepennecsolene@gmail.com

Elodie Perdreau

elodiepm@free.fr

Nicolas Combes

ncombes@clinique-pasteur.com

Leonardo Liberman

11202@cumc.columbia.edu

Christopher J. McLeod

mcleod.christopher@mayo.edu
1 Cardiovascular and Cell Sciences Research Center, St George's University of London, London, UK

2 LIRYC Institute, CHU Bordeaux, Department of Pediatric Cardiology, Bordeaux-II University, Bordeaux, France

3 Service de Cardiologie Pédiatrique, Hôpital du Haut Lévèque, Institut Hospitalo-Universitaire LIRYC (Electrophysiology and Heart Modeling Institute), 5 avenue de Magellan, 33600 Pessac, France

4 Division of Pediatric Electrophysiology, Albert Einstein College of Medicine, Montefiore Children's Hospital, Bronx, NY, USA

5 CHU Rennes, Department of Cardiology, LTSI, INSERM 1099, Rennes-1 University, Rennes, France

6 Department of Cardiology, Clinique Pasteur, Toulouse, France

7 Morgan Stanley Children's Hospital, Division of Pediatric Cardiology, New York Presbyterian Hospital, Columbia University Medical Center, New York, NY, USA

8 Mayo Clinic, Division of Cardiovascular Diseases, Mayo Clinic College of Medicine, Rochester, MN, USA 
Conclusion: Early diagnosis and appropriate management are critical in many cases in order to prevent sudden death, and this review critically assesses our current understanding of the pathogenetic mechanisms, clinical course, and optimal management of congenital and childhood AV block.

\section{What is Known:}

- Prevalence of congenital heart block of 1 per 15,000 to 20,000 live births. AV block is defined as congenital if diagnosed in utero, at birth, or within the first month of life, whereas childhood AV block is diagnosed between the first month and the 18th year of life. As a result of several different etiologies, congenital and childhood atrioventricular block may occur in an entirely structurally normal heart or in association with concomitant congenital heart disease. Cardiac pacing is indicated in symptomatic patients and has several prophylactic indications in asymptomatic patients to prevent sudden death.

- Autoimmune, congenital AV block is associated with a high neonatal mortality rate and development of dilated cardiomyopathy in 5 to $30 \%$ cases.

What is New:

- Several genes including SCN5A have been implicated in autosomal dominant forms of familial progressive cardiac conduction disorders.

- Leadless pacemaker technology and gene therapy for biological pacing are promising research fields. In utero percutaneous pacing appears to be at high risk and needs further development before it can be adopted into routine clinical practice. Cardiac resynchronization therapy is of proven value in case of pacinginduced cardiomyopathy.

Keywords Heart block · Pacemaker · Pathophysiology · Outcomes $\cdot$ Congenital heart disease

\begin{tabular}{ll}
\multicolumn{2}{l}{ Abbreviations } \\
ACC & American College of Cardiology \\
AHA & American Heart Association \\
AV & Atrioventricular \\
CHB & Congenital heart block \\
CHD & Congenital heart disease \\
DCM & Dilated cardiomyopathy \\
ESC & European Society of Cardiology \\
HRS & Heart Rhythm Society \\
PCCD & Progressive cardiac conduction disease \\
SVC & Superior vena cava
\end{tabular}

\section{Background}

Cardiac conduction disorders are rare syndromes in neonates and children $[15,64]$. As a result of several different etiologies, it may occur in an entirely structurally normal heart or in association with concomitant congenital heart disease (CHD). In contrast to acquired atrioventricular (AV) conduction block, congenital heart block (CHB)-identified in utero in normal hearts - holds a significantly different prognosis with an increased risk of late-onset cardiomyopathy. Fundamentally, the pathogenesis is also disparate, driven by different maternal clinical features and an increased risk of recurrence in future pregnancies. For these reasons, AV block is classified as congenital if diagnosed in utero, at birth, or within the first month of life. Therefore, childhood AV block is diagnosed between the first month and the 18th year of life [15]. The estimated prevalence of congenital heart block is 1 per $15,000-20,000$ live births [64].

\section{Atrioventricular conduction disorders in structurally normal hearts}

\section{Immune-mediated AV block}

Although some aspects remain to be clarified, pathophysiology, therapeutic approach, and long-term prognosis of immune-mediated AV block have been extensively studied, as it is one of the leading causes of congenital heart blocks.

Pathophysiology Congenital AV block can be passively acquired via an autoimmune process affecting the developing heart due to the transplacental passage of maternal anti-Ro/SSA and/or anti-La/SSB autoantibodies. Entering the fetal circulation, they can directly bind L-type calcium channels on fetal cardiomyocytes and significantly, but reversibly, inhibit the related currents. However, in some cases, for unclear reasons, the prolonged exposure to anti-Ro/SSA antibodies may induce calcium channel internalization, in turn triggering a complex and only in part mechanistically known perturbation of the cytoplasmic calcium metabolism which ultimately leads to apoptosis and cell death, and then to local inflammation. If the process is not stopped in this phase, the inflammatory damage proceeds, thus eventually resulting in fibrosis and calcification of the cardiac conduction system. This mechanistic sequence, also known as "calcium channel hypothesis," is currently recognized as the more attractive theory possible explaining the pathogenesis of the disease $[1,90]$. Maternal autoantibodies can be detected in over $95 \%$ of fetuses or newborns presenting with AV block, namely congenital AV block [19]. In contrast, maternal autoantibodies have been detected in only a minority of children, in whom AV block was diagnosed beyond the neonatal period, a different, distinct clinical entity [15, 34, 95]. However, some isolated AV blocks diagnosed beyond the neonatal period are also immune-mediated, even with late detection of maternal anti-Ro/SSA autoantibodies [12]. This condition, emerging in childhood or even in the adult age, represents a late progressive congenital form of immune AV block with the late development of a subclinical anti-Ro/SSA-induced congenital damage of the conduction system, related to a not fully understood autoantibody-independent worsening with age [51]. Between 2 
and $5 \%$ of fetuses and infants whose mothers are autoantibodypositive develop AV block, and the risk to subsequent pregnancies is substantial (ranging between 12 and $25 \%$ ) in mothers who have had a child with congenital AV block [16]. In up to a third of infants with congenital AV block, a characterized autoimmune disease, such as lupus, is present in the mother [16]. However, in the large majority of the cases, AV block occurs in fetuses of healthy, silently anti-Ro/SSA antibodies-carrying mothers. The diagnosis of mothers' seropositivity is thus usually made only after congenital AV block detection. In a recent prospective study of 186 antibody-exposed fetuses and infants, it has been demonstrated that mothers of children with cardiac involvement were less likely to have had a connective tissue disease than mothers of children without cardiac involvement [36].

Diagnosis of fetal AV block Fetal echocardiography is the gold standard for the diagnosis of congenital AV block. All M-mode and Doppler echocardiographic techniques rely on the relationship between atrial and ventricular mechanical event [30]. Although clinical applications of both fetal electrocardiography and fetal magnetocardiography are more recent, these two noninvasive tools are promising, being able to more precisely diagnose fetal arrhythmias and conduction disorders $[23,103]$. Complete fetal AV block develops during gestational weeks 16 to 24, although a later onset of the phenomenon up to gestational week 34 has been described $[2,72]$.

Clinical course $\mathrm{CHB}$ derived from an autoimmune process is associated with a high neonatal mortality rate $[16,37]$. The estimated overall mortality without pacing is estimated to be around $8-16 \%$ in infants and half as much in children and adults [37, 65]. Interestingly, cardiac dilatation and impaired ventricular function can develop as long-term sequelae in those who forego pacing and those who are permanently paced. Without pacing support, it appears that the slow heart rates and associated higher stroke volumes probably drive this process [65]. But with pacing, the current hypothesis centers on a pacing-induced cardiomyopathy. Globally, the prevalence of dilated cardiomyopathy (DCM) in $\mathrm{CHB}$ ranges from 5 to $30 \%$ [66, 91, 94]. Various pathophysiological processes, including transient myocarditis or immune-mediated myocardial injury, have been proposed to explain the development of ventricular dilatation and dysfunction. Late-onset dilated cardiomyopathy in patients with complete heart block may be a sequela of in utero autoimmune myocarditis or due to its postnatal reactivation [95]. Right and left ventricular endocardial fibroelastosis and fibrosis have been observed at autopsy. These observations were not limited to the conduction system and involved the working ventricular myocardium. The detrimental effects of maternal antibodies directed against fetal cardiac tissue provided evidence in favor of the immunopathologic role played by the maternal autoantibodies in congenital AV block. In view of the myocardial dystrophic changes and adverse remodeling caused by ventricular desynchronization, right ventricular pacing has been suggested as an important cause of DCM $[66,91,94]$. In some patients, the discontinuation of right ventricular pacing or upgrade to cardiac resynchronization therapy alone normalized systolic function, which would not be expected to occur if ongoing myocarditis or other autoimmune factors were the only cause of DCM [13, 39, 67].

\section{Inherited AV block}

Inherited progressive cardiac conduction disease (PCCD) is diagnosed in patients less than 50 years of age with an unexplained progressive conduction abnormality but with an otherwise structurally normal heart, especially if there is a family history of PCCD. This excludes the skeletal myopathies and muscular dystrophies, given the recognized impact of such progressive disorders on the cardiac muscle [70]. Since the publication of Morquio's first report of familial segregation of heart blocks in 1901, major advances have been made in our understanding of the clinical, genetic, and molecular characteristics of inherited PCCD. Familial clustering of PCCD of unknown cause, including congenital AV block, has been reported. Published pedigrees have shown an autosomal dominant inheritance with incomplete penetrance and variable expressivity $[32,56]$. Inherited PCCD in structurally normal hearts presents as a primary electrical disease and has been linked to genetic variants in the ion channel genes SCN5A, SCN1B, SCN10A, TRPM4, and KCNK17 as well as in genes coding for cardiac connexin proteins [8, 58, 77]. Moreover, SCN5A mutation carriers tend to exhibit "cardiac sodium channelopathy overlap syndrome," with overlapping clinical manifestations of the distinct SCN5A-related syndromes such as long QT syndrome type 3 or Brugada syndrome, and an altered cardiac conduction in many cases [44]. It is now clear that complex pathophysiological processes involving many genes and gene networks may lead to the occurrence of atrioventricular and intraventricular block. It is likely that only a small fraction of these genetic defects have been identified, and it is likely that genetic tests could help in the future to better determine the risk of progression of a conduction defect and hence determine the best timing for pacemaker implantation.

\section{Apparently "idiopathic" AV block}

Rarely, AV block of unknown origin appears during childhood, in the absence of maternal antibodies, structural heart disease, or other overt causes. Scientific literature is scarce regarding the etiology and the clinical course of these patients with apparently idiopathic heart block. In the first large-scale study, looking for heritability of pediatric idiopathic heart block in a French nationwide cohort, Baruteau et al. observed a high degree of inheritance and a strong genetic background in the pathogenesis 
of congenital and childhood nonimmune isolated AV block [9, 10]. Thus, familial screening should be considered and may provide strong arguments for heritability, even in patients where the disorder appears to be sporadic and idiopathic.

\section{Atrioventricular conduction disorders in association with congenital heart disease}

\section{Native}

Recent genetic findings suggest that approximately $10 \%$ of sporadic CHD may have de novo mutations that significantly contribute to the disease process [101]. Mutations in genes encoding for transcription factors critical for cardiac chamber formation, endocardial cushion remodeling, and conduction system development, like $N K X 2.5$ and $T b x 5$, may lead to PCCD associated with CHD [61]. Numerous mutations in $N K X 2.5$ have been reported with various CHD phenotypes, such as secundum atrial septal defect, tetralogy of Fallot, truncus arteriosus, double-outlet right ventricle, Ltransposition of great arteries, interrupted aortic arch, ventricular noncompaction, and hypoplastic left heart, with or without conduction disorders $[62,78]$. Tbx5 mutations are responsible for Holt-Oram syndrome, an autosomal dominant inherited disease characterized by radial ray upper limb abnormalities, cardiac septation defects, and various degrees of cardiac conduction disorders which may occur even in the absence of overt structural heart disease [6].

Kearns-Sayre syndrome is a mitochondrial disorder characterized by onset before the age of 20, progressive external ophthalmoplegia, and pigmentary retinopathy, accompanied by either cardiac conduction defects, elevated cerebrospinal fluid protein, or cerebellar ataxia. Fifty percent of affected patients develop cardiac complications, the most common of them being conduction disease which may progress to complete AV block or bradycardia-related polymorphic ventricular tachycardia [42].

Heart block affects one third of fetuses with heterotaxy syndrome and left atrial isomerism, being a primary risk factor for perinatal mortality [88]. The most common CHD associated with conduction disorders is L-transposition of the great arteries [97]. Abnormal development of the central fibrous body with lack of union between AV node and AV bundle or formation of the conduction tissue from the anterior endocardium were suggested to be the possible causes of block seen in L-transposition [3]. The lifelong risk for complete block in these patients is roughly $1 \%$ annually and roughly $50 \%$ to develop heart block spontaneously by age 50 [97].

\section{Postoperative}

Following CHD surgery, any degree of AV block may be seen (Figs. 1 and 2). A retrospective multicenter study recently evaluated incidence of postoperative complete heart block in children undergoing congenital heart surgery [53]. Among 103,616 surgeries from 45 US tertiary care hospitals, the incidence of complete heart block requiring pacemaker placement was low $(1.2 \%)$, mainly associated with mitral valve repair or replacement $(3.7 \%)$, aortic valve repair or replacement $(2.7 \%)$, atrioventricular canal surgery $(1.9 \%)$, and ventricular septal defect (VSD) surgery (1.8\%). However, these patients incurred longer hospital stay and had higher mortality even after accounting for heart surgery complexity.

In roughly one third of the cases of postoperative complete heart block, AV conduction does not recover and those patients should undergo pacemaker implantation. Permanent pacemaker implantation should be considered in all patients who have postoperative high-grade AV block following CHD surgery that exceeds 7-10 days, even in the setting of a narrow QRS escape rate $[14,26]$. During this period, temporary pacing wires may be necessary to maintain adequate chronotropy. Postoperative heart block has also been rarely reported in patients who had been previously discharged from the hospital with normal AV conduction after open-heart surgery. Close and continued follow-up of postoperative CHD surgical cases, particularly VSD, is necessary due to the risk of possible progression of block over time [54].

\section{Atrioventricular conduction disorders in association with acquired heart disease}

AV block in the young can also be derived from a wide variety of causes such as surgical or catheterization-induced trauma, coronary artery disease, acute or chronic infectious processes, myocarditis, hypersensitivity cardiomyopathy, metabolic abnormalities, hypothyroidism, infiltrative processes, or through a pathological neurocardiogenic mechanism [7]. Even if temporary pacing might be required in unstable patients with Lyme carditis, complete heart block is usually reversible with appropriate antibiotics [28]. Chagas disease is an endemic disease in most Latin American countries, and around one third of affected patients develop cardiac conduction disorders requiring pacemaker implantation [4]. Incidence of catheterization-induced heart block was recently evaluated at $2.2 \%$, with a high rate of recovery following a similar course to that of postsurgical heart block [57]. Some interventional procedures, such as device closure of perimembranous VSD and catheter ablation of AV nodal reentrant tachycardia or parahissian accessory pathways, carry a risk of permanent heart block [49, 100, 102]. The incidence of AV node dysfunction is apparently higher in patients with Kawasaki disease, possibly caused by myocarditis or an abnormal microcirculation in the AV node artery. Acute rheumatic carditis must also be kept in mind in the diagnostic work-up of patients with AV conduction disorder 


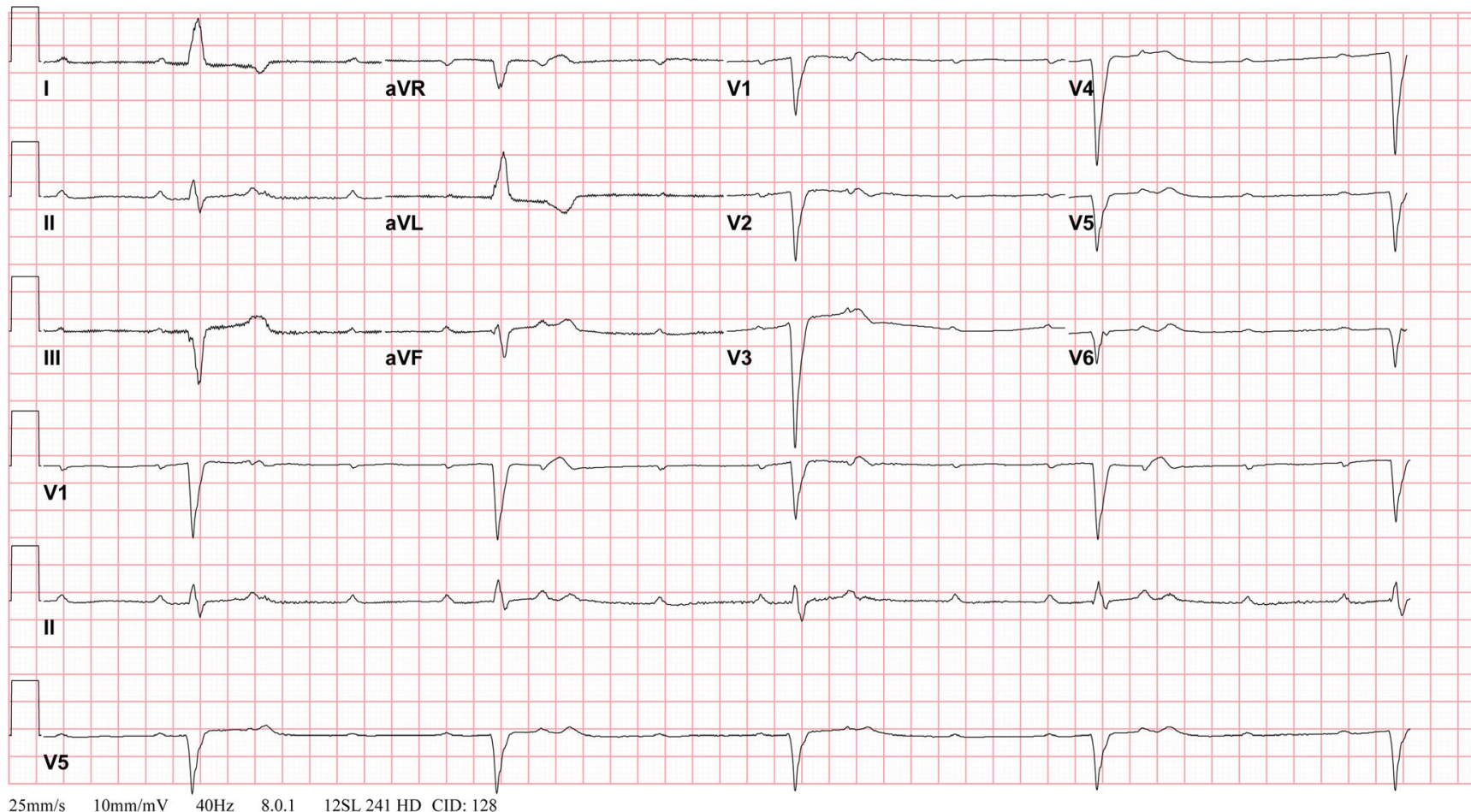

Fig. 1 Complete atrioventricular block: unpaced electrocardiogram. Postoperative 12-lead electrocardiogram demonstrating complete heart block with slow ventricular escape rate, after tricuspid valve replacement

in association with acquired heart disease, particularly when it occurs in pediatric patients; Most cases are reversible firstor second-degree AV blocks. Although a rare and usually transient finding during acute rheumatic fever, complete AV block may lead to symptoms and need a specific treatment.

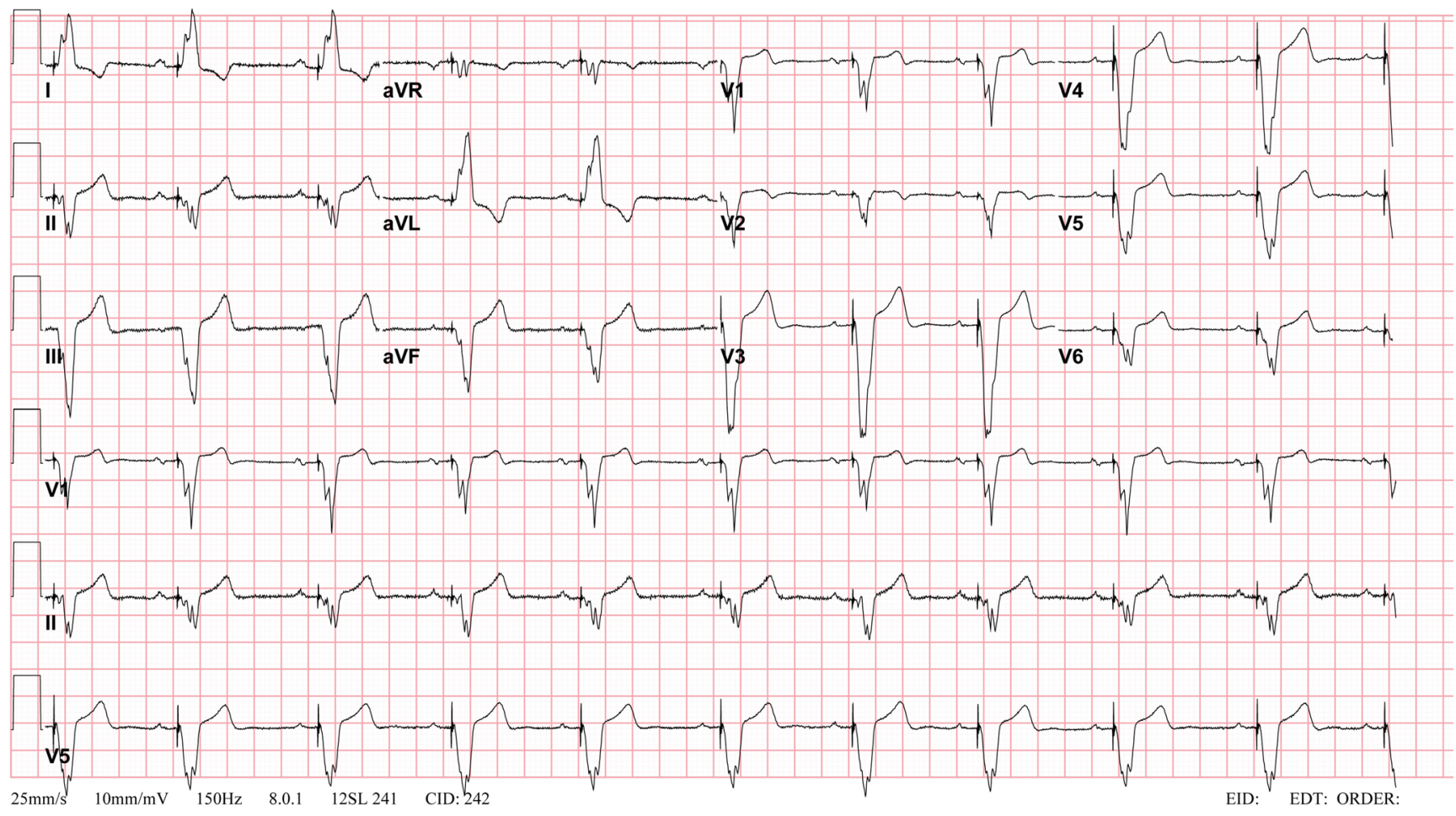

Fig. 2 Complete atrioventricular block: paced electrocardiogram. Twelve-lead electrocardiogram from patient demonstrating atrial sensed ventricular paced rhythm 


\section{Management}

\section{Treatment options during fetal life}

Left untreated, congenital AV block is associated with a fetal and neonatal mortality ranging between 14 and $34 \%$ [76]. Fetal hydrops and ventricular escape rates $<55 \mathrm{bpm}$ have been identified as risk factors for mortality $[54,55]$. Transplacental treatment options are not consensual. Dexamethasone use may significantly lower fetal mortality [38], but its administration remains controversial because of its potential side effects for both mother and fetus, especially potential fetal neurological development impairment [68]. Maternal administration of terbutaline has also been reported, used alone or in addition to dexamethasone [20]. Although largely controversial, prenatal treatment may also include intravenous immunoglobulins and plasmapheresis, used alone or together in combination with steroids $[31,75]$.

Using the currently available techniques, in utero percutaneous pacing appears to be at high risk, with fetal deaths occurring within a few hours of the procedure in a high proportion of cases [5]. Further studies would be required to improve our understanding of the natural history of congenital AV block in order to identify more accurately the fetuses at highest risk. Development in the techniques and technologies available to deliver in utero pacing would also be required before this treatment can be adopted into routine clinical practice.

\section{Postnatal medical therapy}

Pharmacological therapy has a distinct role in the acute management of severe bradycardia (whether sinus- or AV nodalrelated) and should typically be carried out alongside parallel efforts to arrange for transcutaneous pacing and temporary cardiac pacing in order to prevent from sudden cardiac death [48]. Intravenous isoproterenol, atropine, epinephrine, and dopamine are all recommended [48]. Beyond the acute management in this context, no medication is proven to improve chronic sinus- and AV nodal function. It is crucial, however, to recognize the potential for medications to compromise cardiac conduction, especially considering the atypical antihypertensive and antipsychotic agents, in addition to the AV nodal blocking agents they may contain. Monitoring of children who do not require neonatal pacing is based on 24-h Holter ECG and transthoracic echocardiography that should be performed frequently.

\section{Permanent pacemaker implantation}

The indications for permanent pacing in children or adults with $\mathrm{CHD}$ are similar to those recommended in acquired heart disease, yet there are important differences in the approach based primarily on anatomy and somatic growth.
Indications In essence, every symptomatic, non-reversible AV node disease requires permanent pacemaker implantation $[14,26]$. Pacing must also be considered in asymptomatic high degree AV blocks with specific risk conditions. Recent indications for cardiac pacing in children and CHD patients are summarized in Table 1. Although historical series of isolated congenital AV block reported a high incidence of unpredictable Stokes-Adams attacks and a high mortality associated with the first attack $[2,18]$, latest studies performed in our era of pediatric cardiac pacing showed that prophylactic pacing, as currently recommended $[44,45]$, is associated with strong reduction in the morbidity and mortality due to Stokes-Adams attacks [32].

Endocardial versus epicardial device Although pacing indications are clearly defined, whether an endocardial versus an epicardial system is preferred remains to be clarified [26, 48, 96]. The large population of adult paced patients allows for surgical practices to be studied more effectively and lead to evidence-based transitions in patient care. Meanwhile, the smaller volume of paced pediatric patients does not provide enough information and clinical decisions based on faith, opinion, experience, and some retrospective data. Within those limitations, there is a general consensus that the smallest infants are best served with epicardial pacing systems, with a cutoff weight around 15-20 kg [26, 98]. Epicardial leads are more likely to fracture and are prone to exit block, and implantation requires a major operation that is accompanied by the inherent risks and need for perioperative support [89] (Fig. 3). However, many groups standardly use epicardial pacing in infants and young children and argue that endocardial systems may carry a significant risk of venous thrombosis in infants, which can result in loss of venous access in the future, leading to a more complicated lead revision later in the patient's life $[18,29,50]$. Up to a $19 \%$ transvenous lead-related failure rate has been reported by others who choose the endocardial approach [80]. Extraction of abandoned transvenous leads in the pediatric population is also problematic, and optimal lead management still remains to be defined $[17,60]$. On the other hand, there is a global trend towards using endocardial leads in younger patients and some institutions actively implant transvenous leads in children weighing less than $15 \mathrm{~kg}[43,63,73,79,83,85]$. It has been shown that an 80-mm right atrial lead loop will allow 6 to 12 years (mean, 8 years) of growth in infants and children without the need for reoperation to adjust lead length [33] (Figs. 4, 5 and 6). Long-term follow-up demonstrates that the longevity of an endocardial system exceeds that of its epicardial counterpart [89, 98], also an important consideration in patients who will be exposed to the cumulative burden of repeated lead and device reimplantation. Despite growing experience, endocardial implantation is not universally accepted. Most publications reporting results of transvenous 
Table 1 Pacing indications in children and patients with congenital heart disease

ESC guidelines

ACCF/AHA/HRS guidelines

Congenital AV block

Symptomatic advanced second- or third-degree AV block

Asymptomatic high degree AV block with ventricular dysfunction

Asymptomatic high degree AV block with prolonged QTc interval

Asymptomatic high degree AV block with complex ventricular ectopy

Asymptomatic high degree AV block with wide QRS escape rhythm

Asymptomatic high degree AV block with abrupt ventricular pauses $>$ threefold the basic cycle length

Asymptomatic third-degree AV block in the infant with a ventricular rate $<55 \mathrm{bpm}$ or with CHD and a ventricular rate $<70 \mathrm{bpm}$

Third-degree AV block beyond the first year of life with an average heart rate $<50 \mathrm{bpm}$

Asymptomatic high degree AV block with a ventricular rate $<50 \mathrm{bpm}$

Third-degree AV block beyond the first year of life with symptoms due to chronotropic incompetence

High degree AV block in asymptomatic children/adolescents in absence of the above risk conditions

Asymptomatic type I second-degree AV block

Postoperative AV block

Postoperative advanced second- or third-degree AV block that persists

$>7$ days after cardiac surgery (10 days in ESC guidelines)

Transient postoperative third-degree AV block that reverts to sinus rhythm with residual bifascicular block

Unexplained syncope in the patient with prior CHD surgery complicated by transient complete heart block with residual fascicular block

Transient postoperative AV block with return of normal AV conduction in the otherwise asymptomatic patient

Asymptomatic postoperative bifascicular block with/without first-degree $\mathrm{AV}$ block in the absence of prior transient complete AV block

$\begin{array}{ll}\text { Class I, level C } & \text { Class I, level C } \\ \text { Class I, level C } & \text { Class I, level B } \\ \text { Class I, level C } & - \\ \text { Class I, level C } & \text { Class I, level B } \\ \text { Class I, level C } & \text { Class I, level B } \\ \text { Class I, level C } & \text { Class IIa, level B } \\ - & \text { Class I, level C } \\ - & \text { Class IIa, level B }\end{array}$

Class I, level C

Class IIa, level B

Class IIb, level C Class IIb, level B

Class III, level C

Class I, level B

Class I, level B

Class IIa, level C

Class IIb, level C

Class IIa, level B

Class III, level B

Class III, level C

Levels of evidence are classified in "level A" if data are derived from multiple randomized clinical trials or meta-analyses, "level B" if data are derived from a single randomized clinical trial or large non-randomized studies, and "level C" if there is a consensus of opinion of the experts and/or if data are derived from small studies, retrospective studies, or registries. Recommendations are listed according to the commonly used class I, IIa, IIb, and III classification and the corresponding language: "is recommended" for a class I recommendation; "can be useful" for a class IIa recommendation; "may be considered" to signify a class IIb recommendation; and "should not" or "is not recommended" for a class III recommendation. ESC guidelines: reference [44]; ACCF/AHA/HRS guidelines: reference [45]

$A V$ atrioventricular, $C H D$ congenital heart disease

pacing in infants and young children are from small and/or older studies [33, 40, 43, 55], so that long-term follow-up data from large patient populations should still be clarified.

Route of pacing Gaining access to the chamber requiring pacing is another central hurdle, frequently challenging in this patient group, and thereby commonly dictating the route of pacing but also highlighting why a detailed surgical history is vital. Modern-day pacemaker implantation is therefore suitably complemented by adjunctive CT or MR angiography, indicating whether an endocardial system is possible, and also providing a map for coronary sinus lead placement. For complex CHD patients with prior operative intervention and whose surgical reports are not available, venography at the time of the procedure is recommended [14, 26]. Absolute contraindications to conventional transvenous, endocardial lead placement include occlusion of the superior vena cava
(SVC) (bidirectional cavopulmonary anastomosis/Glenn), extra-cardiac Fontan procedures, baffle thrombosis, and severe baffle stenosis. Attempts to access the subpulmonic ventricle by crossing a mechanical atrioventricular valve should also absolutely be avoided [27]. In this situation, coronary sinus lead placement can potentially be used for ventricular pacing.

In patients in whom a conventional transvenous approach via the SVC is not possible, femoral and transhepatic lead implantation can also be considered. Femoral techniques have been reported predominantly in children, suggesting this is a viable alternative with issues related primarily to the stability of the atrial lead and discomfort from the abdominally placed generator [59]. This approach does entail a higher incidence of lead failure given the additional mechanical stress associated with hip flexion. Transhepatic implants have also only been reported in children and acutely present the additional risks of 


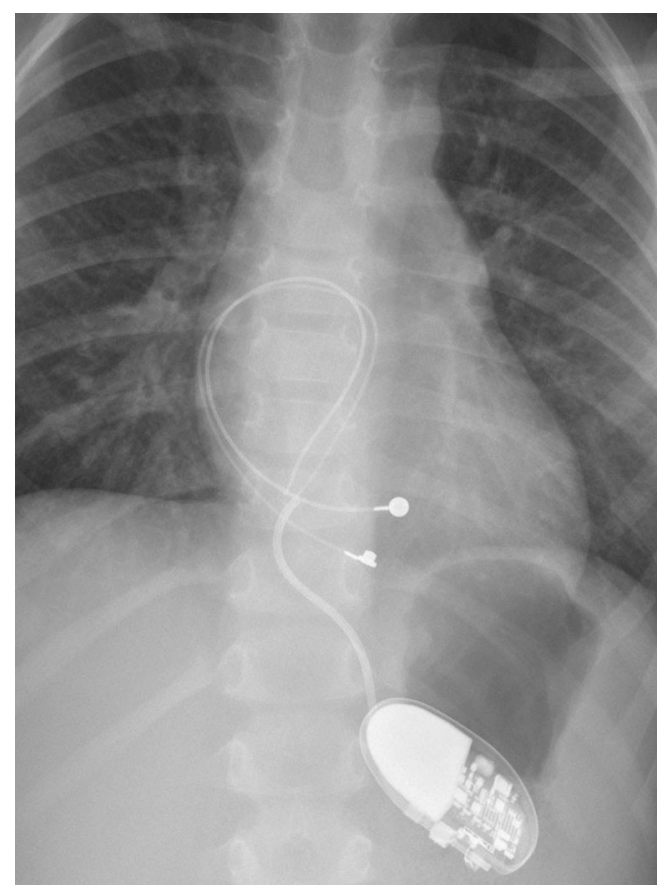

Fig. 3 Permanent pacemaker with epicardial leads (VVI pacing)

intraabdominal or intracapsular hemorrhage, and long-term outcomes remain uncertain [25].

Placing leads in patients with prior atrial switch operations (Mustard/Senning) must be handled with utmost care, given the frequency of baffle leaks in this group [47]. Pre-emptive covered stent implantation or even open repair should be considered given the risk of thromboembolism across these venosystemic shunts. A transcatheter approach is utilized for leak closure but can also be applied for dilatation of a narrowed baffle that would otherwise be occluded by transvenous lead implantation [11, 24].

Thromboembolism Any patient with an intracardiac shunt is at higher risk for thrombus formation on transvenous pacing leads and subsequent systemic thromboembolic complications $[21,45]$. Pre-emptive transesophageal echocardiography with bubble injections is therefore critical, and if any shunt is seen, the approach should be modified. If the shunt can be closed, either via an open approach or using a percutaneous approach, then this should be undertaken before endocardial leads are placed or alternatively an epicardial device should be implanted. It remains unclear how to exactly manage patients with a small shunt at an atrial level across a patent foramen ovale and further studies would be needed to develop recommendations [21]. It is also vital to recognize that the patients with a classic Fontan operation frequently have very large atria and slow flow through their neo-chamber. Thus, it is not uncommon for large thrombi with a potential for pulmonary thromboembolism to develop on transvenous leads. And although this does not present an absolute contraindication $[69,87]$, it does need to be
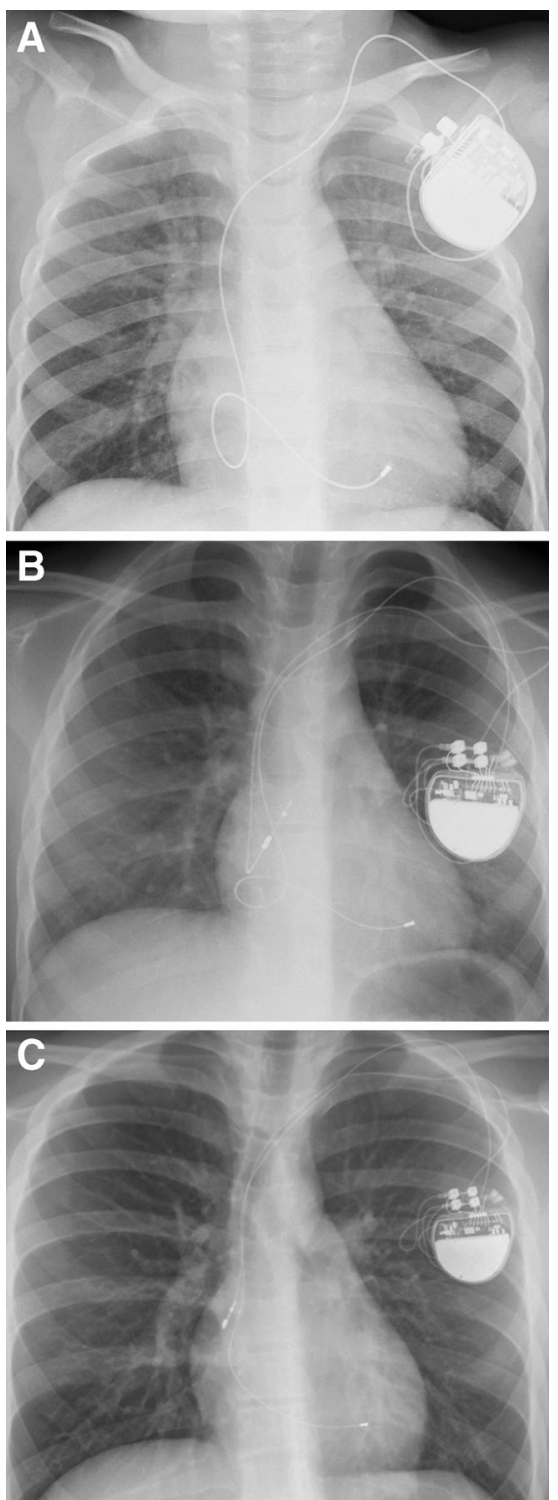

Fig. 4 Permanent pacemaker with transvenous leads. Growth and change in a loop of an endocardial lead. A 4-year-old boy with childhood isolated nonimmune atrioventricular block underwent pacemaker implantation using a transvenous lead. Radiographs at 4 years of age (a, VVI pacing), 6 years later (b, DDD pacing), and 9 years later (c, DDD pacing). Note the change in the loop of the lead as the child grows

carefully considered and weighed against the risks of epicardial lead placement. Long-term oral anticoagulation does also need to be accordingly considered in this group.

Lead position The pacing site of the ventricular leads is a critical issue, as it has a major impact on left ventricular mechanical synchrony, efficiency, and pump function in children who require lifelong pacing. The right ventricular apex has been the most used pacing site, because it is easily accessible transvenously and provides a stable lead position with a low dislodgment rate. However, long-term right ventricular apical pacing induces an iatrogenic left bundle branch block and can lead to pacinginduced cardiomyopathy with left ventricular dilation and both 


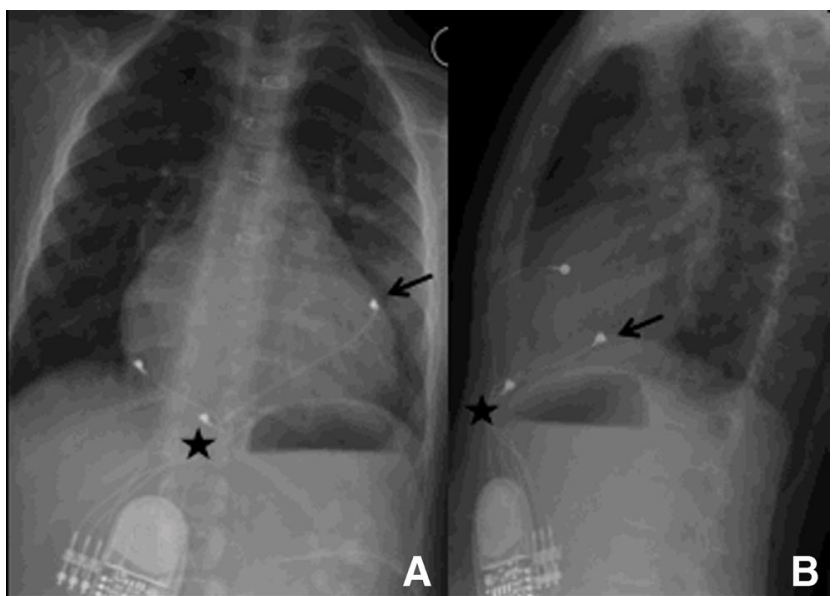

B

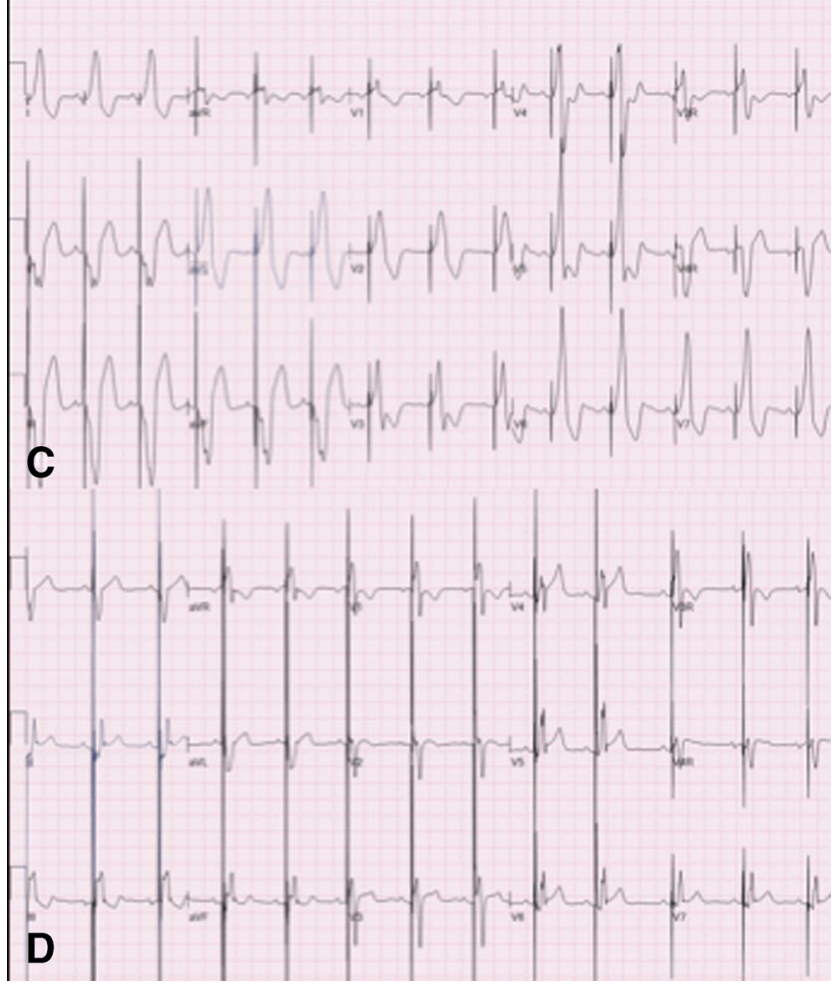

Fig. 5 Cardiac resynchronization therapy with epicardial leads. A 5-yearold boy who underwent a neonatal Ross procedure had postoperative complete heart block and left ventricular dysfunction. He was implanted with epicardial multisite pacing with right atrial, right ventricular (a and $\mathbf{b}$, black star), and left ventricular (a and $\mathbf{b}$, black arrow) leads. Biventricular pacing allow shortening of the paced QRS (c, $224 \mathrm{~ms}$ ) compared with right ventricular pacing alone (d, $128 \mathrm{~ms})$

systolic and diastolic left ventricular dysfunction, for both endocardial and epicardial leads $[46,67,86,91,99]$. There is early encouraging data that suggest improved overall hemodynamics and ventricular function by cardiac resynchronization therapy with single-site left ventricular pacing via the coronary sinus in this group [41]. Until further supportive evidence is accrued, it is important for the implanter and clinician to consider this approach in any patient whose ejection fraction is suboptimal.

However, detrimental effects of the right ventricular apical pacing led to the reassessment of traditional approaches and to

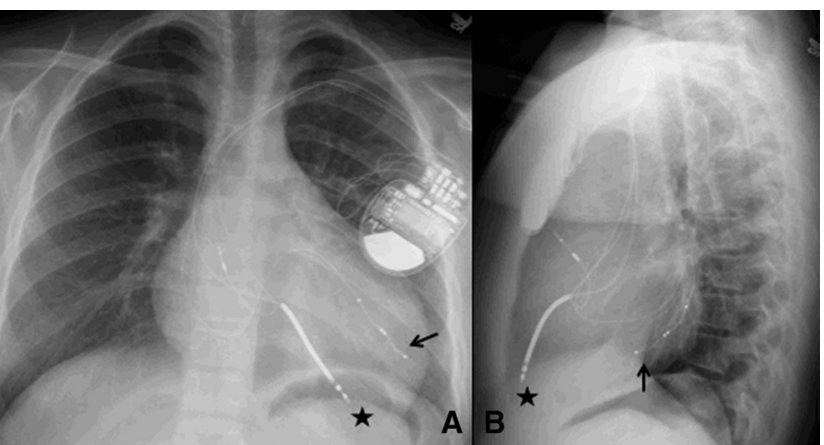

Fig. 6 Cardiac resynchronization therapy with transvenous leads. A 14year-old boy with dilated cardiomyopathy and left ventricular dysfunction, second-degree AV block, and an episode of ventricular fibrillation had implantation of a biventricular implantable cardioverter-defibrillator with a transvenous right ventricular lead ( $\mathbf{a}$ and $\mathbf{b}$, black star) and a transvenous left ventricular lead into the coronary sinus (a and $\mathbf{b}$, black arrow)

the research of alternative pacing sites, in order to get to more physiological pattern of ventricular activation. Although being theoretically the best technique, direct His-Bundle pacing and paraHisian cardiac pacing remain complex and associated with higher pacing thresholds are required, causing accelerated battery depletion [93]. Right ventricular septal pacing is a good alternative, technically easy and maintaining a lower pacing threshold [22]. By preserving septal to lateral left ventricular synchrony and systolic function, left ventricular apical and midlateral wall pacing may be the preferred pacing site for epicardial leads in the young [41, 81].

Mode of pacing A five-letter international code describes pacemaker function, three letters being in common usage: the first letter is the chamber paced $(\mathrm{A}=$ atrium; $\mathrm{V}=$ ventricle; $\mathrm{D}=$ dual, namely both $\mathrm{A}$ and $\mathrm{V} ; \mathrm{O}=$ none), the second letter is the chamber sensed and the third letter describes the algorithm used to integrate pacing and sensing functions. Most of children and teenagers will benefit from a dual-chamber pacing (DDD), allowing AV synchrony that is important to maintain ventricular filling and stroke volume [89, 96]. In infants with complete AV block and normal sinus node function, a singlechamber ventricular pacing (VVI or VDD) should be selected, because it requires only a unique lead (uni- or bipolar) thus reducing the risk of venous occlusion $[89,96]$.

In patients with conduction system disease undergoing pacemaker implantation, coexistent reentrant atrial tachycardias are common. Therefore, the implantation of devices with atrial antitachycardia pacing capability is reasonable [84]. This approach is more common as an adjunct to maze procedures and in conjunction with antiarrhythmic therapy [92].

Perspectives To overcome the potential short- and long-term complications related to transvenous leads and subcutaneous pulse generators, new technologies enabling leadless cardiac 
stimulation have been developed and proved to be applicable and safe in experimental models and in some small human studies $[52,71,82]$. These ultrasound or induction technologies, based on leadless pacemakers, could be used to provide cardiac stimulation from the endocardium at selected sites. The absence of a transvenous lead and subcutaneous pulse generator could represent a paradigm shift in cardiac pacing. Future studies will need to address the safety/efficacy of alternate-site $\mathrm{RV}$ and LV pacing and the long-term outcomes of these new approaches. Although the continued development and success of electronic pacing are impressive, gene therapy for biological pacing is also a promising research field. This approach might offer an alternative treatment for pacemaker-related infections in the future, with right ventricular intramyocardial injection of an adenoviral construct whose duration of effect is temporary, until such time as the infection is adequately treated and a new permanent pacemaker can be inserted [35, 74].

\section{Conclusion}

Although rare, congenital and childhood AV block is important treatable cause of morbidity and mortality in the young. This review crystallizes our contemporary understanding and management strategies, highlighting the ongoing investigation in all aspects of care related to this complex group of disorders. Much work is needed, especially with regards to the antenatal detection and treatment of congenital AV block, and on a genetic level, and it is evident that as new insights are gleaned, management strategies continue to evolve. Despite the many different etiologies, each with specific management and distinct outcomes, these patients can do well with a careful, considered approach to the diagnostic evaluation and management plan.

Acknowledgments Dr. Baruteau is supported by the 2015 Academic Research Grant from the European Heart Rhythm Association and a research grant from the Lefoulon Delalande Foundation - Institut de France.

Author's contribution Dr. Baruteau conceptualized and designed the review article, drafted several parts of its initial version, and approved the final manuscript as submitted. Dr. Pass drafted the paragraph on postoperative heart blocks and the one on native heart blocks associated with congenital heart disease. He approved the final manuscript as submitted. Dr. Thambo drafted the paragraph on immune-mediated AV block. He approved the final manuscript as submitted. Dr. Behaghel drafted the part describing permanent pacemaker implantation. He approved the final manuscript as submitted. Dr. Le Pennec drafted the paragraph on treatment options during pregnancy and critically revised the initial version of the paper. She approved the final manuscript as submitted. Dr. Perdreau drafted the part on native heart blocks associated with congenital heart disease. She approved the final manuscript as submitted. Drs. Liberman and Combes critically reviewed the article and added substantial contents to this paper. They approved the final manuscript as submitted. Dr. McLeod drafted the management section. He critically reviewed the whole paper and approved the final manuscript as submitted.
All authors approved the final manuscript as submitted and agreed to be accountable for all aspects of the work.

\section{Compliance with ethical standards}

Financial disclosure None of the authors has any financial relationships relevant to this article to disclose.

Conflict of interest The authors declare that they have no conflict of interest.

Funding None.

Ethical approval This article does not contain any studies with human participants or animals performed by any of the authors.

Open Access This article is distributed under the terms of the Creative Commons Attribution 4.0 International License (http:// creativecommons.org/licenses/by/4.0/), which permits unrestricted use, distribution, and reproduction in any medium, provided you give appropriate credit to the original author(s) and the source, provide a link to the Creative Commons license, and indicate if changes were made.

\section{References}

1. Ambrosi A, Wahren-Herlenius M (2012) Congenital heart block: evidence for a pathogenic role of maternal autoantibodies. Arthritis Res Ther 14:208

2. Andelfinger G, Fouron JC, Sonesson SE, Proulx F (2001) Reference values for time intervals between atrial and ventricular contractions of the fetal heart measured by two Doppler techniques. Am J Cardiol 88:1433-6

3. Anderson RH, Becker AE, Arnold R, Wilkinson JL (1974) The conducting tissues in congenitally corrected transposition. Circulation 50:911-923

4. Arce M, Van Grieken J, Femenía F, Arrieta M, McIntyre WF, Baranchuk A (2012) Permanent pacing in patients with Chagas' disease. Pacing Clin Electrophysiol 35:1494-7

5. Assad RS, Zielinsky P, Kalil R, Lima G, Aramayo A, Santos A, Costa R, Marcial MB, Oliveira SA (2003) New lead for in utero pacing for fetal congenital heart block. J Thorac Cardiovasc Surg 126:300-2

6. Baban A, Pitto L, Pulignani S, Cresci M, Mariani L, Gambacciani C, Digilio MC, Pongiglione G, Albanese S (2014) Holt-Oram syndrome with intermediate atrioventricular canal defect, and aortic coarctation: functional characterization of a de novo TBX5 mutation. Am J Med Genet A 164A:1419-24

7. Barra SN, Providência R, Paiva L, Nascimento J, Marques AL (2012) A review on advanced atrioventricular block in young or middle-aged adults. Pacing Clin Electrophysiol 35:1395-405

8. Baruteau AE, Probst V, Abriel H (2015) Inherited progressive cardiac conduction disorders. Curr Opin Cardiol 30:33-39

9. Baruteau AE, Fouchard S, Behaghel A, Mabo P, Villain E, Thambo JB, Marçon F, Gournay V, Rouault F, Chantepie A, Guillaumont S, Godart F, Bonnet C, Fraisse A, Schleich JM, Lusson JR, Dulac Y, Leclercq C, Daubert JC, Schott JJ, Le Marec H, Probst V (2012) Characteristics and long-term outcome of nonimmune isolated atrioventricular block diagnosed in utero or early childhood: a multicentre study. Eur Heart J 33:622-629

10. Baruteau AE, Behaghel A, Fouchard S, Mabo P, Schott JJ, Dina C, Chatel S, Villain E, Thambo JB, Marçon F, Gournay V, Rouault F, Chantepie A, Guillaumont S, Godart F, Martins RP, Delasalle B, Bonnet C, Fraisse A, Schleich JM, Lusson JR, Dulac Y, Daubert 
JC, Le Marec H, Probst V (2012) Parental electrocardiographic screening identifies a high degree of inheritance for congenital and childhood non-immune isolated atrioventricular block. Circulation 126:1469-1477

11. Bentham J, English K, Hares D, Gibbs J, Thomson J (2012) Effect of transcatheter closure of baffle leaks following senning or mustard atrial redirection surgery on oxygen saturations and polycythaemia. Am J Cardiol 110:1046-1050

12. Bergman G, Skog A, Tingström J, Ottosson V, Hoxha A, Ambrosi A, Swedish Congenital Heart Block Study Group, Salomonsson S, Wahren-Herlenius M (2014) Late development of complete atrioventricular block may be immune mediated and congenital in origin. Acta Paediatr 103:275-81

13. Bordachar P, Zachary W, Ploux S, Labrousse L, Haissaguerre M, Thambo JB (2013) Pathophysiology, clinical course, and management of congenital complete atrioventricular block. Heart Rhythm 10:760-6

14. Brignole M, Auricchio A, Baron-Esquivias G, Bordachar P, Boriani G, Breithardt OA, Cleland J, Deharo JC, Delgado V, Elliott PM, Gorenek B, Israel CW, Leclercq C, Linde C, Mont L, Padeletti L, Sutton R, Vardas PE, ESC Committee for Practice Guidelines (CPG), Zamorano JL, Achenbach S, Baumgartner H, Bax JJ, Bueno H, Dean V, Deaton C, Erol C, Fagard R, Ferrari R, Hasdai D, Hoes AW, Kirchhof P, Knuuti J, Kolh P, Lancellotti P, Linhart A, Nihoyannopoulos P, Piepoli MF, Ponikowski P, Sirnes PA, Tamargo JL, Tendera M, Torbicki A, Wijns W, Windecker S, Document Reviewers, Kirchhof P, Blomstrom-Lundqvist C, Badano LP, Aliyev F, Bänsch D, Baumgartner H, Bsata W, Buser P, Charron P, Daubert JC, Dobreanu D, Faerestrand S, Hasdai D, Hoes AW, Le Heuzey JY, Mavrakis H, McDonagh T, Merino JL, Nawar MM, Nielsen JC, Pieske B, Poposka L, Ruschitzka F, Tendera M, Van Gelder IC, Wilson CM (2013) 2013 ESC guidelines on cardiac pacing and cardiac resynchronization therapy: the task force on cardiac pacing and resynchronization therapy of the European Society of Cardiology (ESC). Developed in collaboration with the European Heart Rhythm Association (EHRA). Eur Heart J 34:2281-2329

15. Brucato A, Jonzon A, Friedman D, Allan LD, Vignati G, Gasparini M, Stein JI, Montella S, Michaelsson M, Buyon J (2003) Proposal for a new definition of congenital complete atrioventricular block. Lupus 12:427-35

16. Buyon JP, Hiebert R, Copel J, Craft J, Friedman D, Katholi M, Lee LA, Provost TT, Reichlin M, Rider L, Rupel A, Saleeb S, Weston WL, Skovron ML (1998) Autoimmune-associated congenital heart block: demographics, mortality, morbidity and recurrence rates obtained from a national neonatal lupus registry. J Am Coll Cardiol 31:1658-66

17. Cecchin F, Atallah J, Walsh EP, Triedman JK, Alexander ME, Berul CI (2010) Lead extraction in pediatric and congenital heart disease patients. Circ Arrhythm Electrophysiol 3:437-44

18. Cohen MI, Bush DM, Vetter VL, Tanel RE, Wieand TS, Gaynor JW, Rhodes LA (2001) Permanent epicardial pacing in pediatric patients: seventeen years of experience and 1200 outpatient visits. Circulation 103:2585-2590

19. Costedoat-Chalumeau N, Georgin-Lavialle S, Amoura Z, Piette JC (2005) Anti-SSA/Ro and anti-SSB/La antibody-mediated congenital heart block. Lupus 14:660-4

20. Cuneo BF, Lee M, Roberson D, Niksch A, Ovadia M, Parilla BV, Benson DW (2010) A management strategy for fetal immunemediated atrioventricular block. J Matern Fetal Neonatal Med 23: $1400-5$

21. DeSimone CV, Friedman PA, Noheria A, Patel NA, DeSimone DC, Bdeir S, Aakre CA, Vaidya VR, Slusser JP, Hodge DO, Ackerman MJ, Rabinstein AA, Asirvatham SJ (2013) Stroke or transient ischemic attack in patients with transvenous pacemaker or defibrillator and echocardiographically detected patent foramen ovale. Circulation 128:1433-1441

22. Deshmukh P, Casavant DA, Romanyshyn M, Anderson K (2000) Permanent, direct His-bundle pacing: a novel approach to cardiac pacing in patients with normal His-Purkinje activation. Circulation 101:869-77

23. Donofrio MT, Moon-Grady AJ, Hornberger LK, Copel JA, Sklansky MS, Abuhamad A, Cuneo BF, Huhta JC, Jonas RA, Krishnan A, Lacey S, Lee W, Michelfelder EC Sr, Rempel GR, Silverman NH, Spray TL, Strasburger JF, Tworetzky W, Rychik J, American Heart Association Adults With Congenital Heart Disease Joint Committee of the Council on Cardiovascular Disease in the Young and Council on Clinical Cardiology, Council on Cardiovascular Surgery and Anesthesia, and Council on Cardiovascular and Stroke Nursing (2014) Diagnosis and treatment of fetal cardiac disease: a scientific statement from the American Heart Association. Circulation 129:2183-242

24. Dragulescu A, Sidibe N, Aubert F, Fraisse A (2008) Successful use of covered stent to treat superior systemic baffle obstruction and leak after atrial switch procedure. Pediatr Cardiol 29:954-956

25. Emmel M, Sreeram N, Pillekamp F, Boehm W, Brockmeier K (2006) Transhepatic approach for catheter interventions in infants and children with congenital heart disease. Clin Res Cardiol 95:329-333

26. Epstein AE, DiMarco JP, Ellenbogen KA, Estes NA 3rd, Freedman RA, Gettes LS, Gillinov AM, Gregoratos G, Hammill SC, Hayes DL, Hlatky MA, Newby LK, Page RL, Schoenfeld MH, Silka MJ, Stevenson LW, Sweeney MO, Tracy CM, Epstein AE, Darbar D, DiMarco JP, Dunbar SB, Estes NA 3rd, Ferguson TB Jr, Hammill SC, Karasik PE, Link MS, Marine JE, Schoenfeld MH, Shanker AJ, Silka MJ, Stevenson LW, Stevenson WG, Varosy PD (2013) 2012 ACCF/AHA/HRS focused update incorporated into the ACCF/ AHA/HRS 2008 guidelines for device-based therapy of cardiac rhythm abnormalities: a report of the American College of Cardiology Foundation/American Heart Association Task Force on Practice Guidelines and the Heart Rhythm Society. J Am Coll Cardiol 61:e6-75

27. Fadel BM, Di Salvo G (2013) Metal through metal: pacing lead across a mechanical tricuspid valve. J Cardiovasc Med

28. Forrester JD, Mead P (2014) Third-degree heart block associated with Lime carditis: review of published cases. Clin Infect Dis 59:996-1000

29. Fortescue EB, Berul CI, Cecchin F, Walsh EP, Triedman JK, Alexander ME (2004) Patient, procedural, and hardware factors associated with pacemaker lead failures in pediatrics and congenital heart disease. Heart Rhythm 1:150-159

30. Fouron JC, Proulx F, Miro J, Gosselin J (2000) Doppler and M-mode ultrasonography to time fetal atrial and ventricular contractions. Obstet Gynecol 96:732-6

31. Friedman DM, Llanos C, Izmirly PM, Brock B, Byron J, Copel J, Cummiskey K, Dooley MA, Foley J, Graves C, Hendershott C, Kates R, Komissarova EV, Miller M, Paré E, Phoon CK, Prosen T, Reisner D, Ruderman E, Samuels P, Yu JK, Kim MY, Buyon JP (2010) Evaluation of fetuses in a study of intravenous immunoglobulin as preventive therapy for congenital heart block: results of a multicenter, prospective, open-label clinical trial. Arthritis Rheum 62:1138-46

32. Gazes PC, Culler RM, Taber E, Kelly TE (1965) Congenital familial cardiac conduction defects. Circulation 32:32-4

33. Gheissari A, Hordof AJ, Spotnitz HM (1991) Transvenous pacemakers in children: relation of lead length to anticipated growth. Ann Thorac Surg 52:118-21

34. Hunscher O, Batista N, Rivero S, Marletta C, Arriagada M, Boire G, Ménard HA, Arana RM (1995) Clinical and serological identification of 2 forms of complete heart block in children. J Rheumatol 22: 1352-5.7

35. Hu Y-F, Dawkins JF, Cho HC, Marban E, Cingolani E (2014) Biological pacemaker created by minimally invasive somatic reprogramming in pigs with complete heart block. Sci Transl Med 6:245-94

36. Jaeggi E1, Laskin C, Hamilton R, Kingdom J, Silverman E (2010) The importance of the level of maternal anti-Ro/SSA antibodies as a prognostic marker of the development of cardiac neonatal lupus 
erythematosus a prospective study of 186 antibody-exposed fetuses and infants. J Am Coll Cardiol 55:2778-84

37. Jaeggi ET, Hamilton RM, Silverman ED, Zamora SA, Hornberger LK (2002) Outcome of children with fetal, neonatal or childhood diagnosis of isolated congenital atrio-ventricular block. J Am Coll Cardiol 39:130-7

38. Jaeggi ET, Fouron JC, Silverman ED, Ryan G, Smallhorn J, Hornberger LK (2004) Transplacental fetal treatment improves the outcome of prenatally diagnosed complete atrioventricular block without structural heart disease. Circulation 110: $1542-8$

39. Janousek J, Tomek V, Chaloupecky V, Gebauer RA (2004) Dilated cardiomyopathy associated with dual-chamber pacing in infants: improvement through either left ventricular cardiac resynchronization or programming the pacemaker off allowing intrinsic normal conduction. J Cardiovasc Electrophysiol 15: $470-4$

40. Janousek J, Kubus P (2014) What's new in cardiac pacing in children? Curr Opin Cardiol 29:76-82

41. Janousek J, van Geldorp IE, Krupickova S, Rosenthal E, Nugent K, Tomaske M, Früh A, Elders J, Hiippala A, Kerst G, Gebauer RA, Kubuš P, Frias P, Gabbarini F, Clur SA, Nagel B, Ganame J, Papagiannis J, Marek J, Tisma-Dupanovic S, Tsao S, Nürnberg JH, Wren C, Friedberg M, de Guillebon M, Volaufova J, Prinzen FW, Delhaas T, Working Group for Cardiac Dysrhythmias and Electrophysiology of the Association for European Pediatric Cardiology (2013) Permanent cardiac pacing in children: choosing the optimal pacing site: a multicenter study. Circulation 127: 613-623

42. Kabunga P, Lau AK, Phan K, Puranik R, Liang C, Davis RL, Sue CM, Sy RW (2015) Systematic review of cardiac electrical disease in Kearns-Sayre syndrome and mitochondrial cytopathy. Int J Cardiol 181:303-310

43. Kammeraad J, Rosenthal E, Bostock J, Rogers J, Sreeram N (2004) Endocardial pacemaker implantation in infants $<10 \mathrm{~kg}$ weight. Pacing Clin Electrophysiol 27:1466-74

44. Kanter RJ, Pfeiffer R, Hu D, Barajas-Martinez H, Carboni MP, Antzelevitch C (2012) Brugada-like syndrome in infancy presenting with rapid ventricular tachycardia and intraventricular conduction delay. Circulation 125:14-22

45. Khairy P, Landzberg MJ, Gatzoulis MA, Mercier LA, Fernandes SM, Côté JM, Lavoie JP, Fournier A, Guerra PG, Frogoudaki A, Walsh EP, Dore A, Epicardial Versus ENdocardial pacing and Thromboembolic events Investigators, (2006) Transvenous pacing leads and systemic thromboemboli in patients with intracardiac shunts: a multicenter study. Circulation 113:2391-2397

46. Kim JJ, Friedman RA, Eidem BW, Cannon BC, Arora G, Smith EO, Fenrich AL, Kertesz NJ (2007) Ventricular function and long-term pacing in children with congenital complete atrioventricular block. J Cardiovasc Electrophysiol 18:373-377

47. Klein AJ, Kim MS, Salcedo E, Fagan T, Kay J (2009) The missing leak: a case report of a baffle-leak closure using real-time $3 \mathrm{~d}$ transoesophageal guidance. Eur J Echocardiogr 10:464-467

48. Kleinman ME, de Caen AR, Chameides L, Samson RA, Hazinski MF, Atkins DL, Berg MD, de Caen AR, Fink EL, Freid EB, Hickey RW, Marino BS, Nadkarni VM, Proctor LT, Qureshi FA, Sartorelli K, Topjian A, van der Jagt EW, Zaritsky AL, American Heart Association. Pediatric Basic and Advanced Life Support Chapter Collaborators (2010) Pediatric basic and advanced life support: 2010 International Consensus on Cardiopulmonary Resuscitation and Emergency Cardiovascular Care Science with Treatment Recommendations. Pediatrics 126:e1261-318

49. Krause U, Backhoff D, Klehs S, Kriebel T, Paul T, Schneider HE (2015) Catheter ablation of pediatric AV nodal reentrant tachycardia: results in small children. Clin Res Cardiol 104:990-7
50. Kubus P, Materna O, Gebauer RA, Matejka T, Gebauer R, Tláskal T, Janousek J (2012) Permanent epicardial pacing in children: long-term results and factors modifying outcome. Europace 14: 509-14

51. Lazzerini PE, Capecchi PL, Laghi-Pasini F (2015) Isolated atrioventricular block of unknown origin in adults and anti-Ro/SSA antibodies: clinical evidence, putative mechanisms, and therapeutic implications. Heart Rhythm 12:449-54

52. Lee KL, Lau CP, Tse HF, Echt DS, Heaven D, Smith W, Hood M (2007) First human demonstration of cardiac stimulation with transcutaneous ultrasound energy delivery: implications for wireless pacing with implantable devices. J Am Coll Cardiol 50:877-83

53. Liberman L, Silver ES, Chai P, Anderson BR (2016) Incidence and characteristics of heart block after heart surgery in pediatric patients: a multicenter study. J Thorac Cardiovasc Surg. doi:10.1016/j. jtcvs.2016.03.081

54. Liberman L, Pass RH, Hordof AJ, Spotnitz HM (2008) Late onset of heart block after open heart surgery for congenital heart disease. Pediatr Cardiol 29:56-9

55. Lotfy W, Hegazy R, Abdelaziz O, Sobhy R, Hasanein H, Shaltout F (2013) Permanent cardiac pacing in pediatric patients. Pediatr Cardiol 34:273-280

56. Lynch HT, Mohiuddin S, Sketch MH, Krush AJ, Carter S, Runco V (1973) Hereditary progressive atrioventricular conduction defect. A new syndrome? JAMA 225:1465-70

57. Mah DY, Porras D, Bergersen L, Marshall AC, Walsh EP, Triedman JK (2014) Incidence of and risk factors for catheterization-induced complete heart block in the pediatric cardiac catheterization laboratory. Circ Arrhythm Electrophysiol 7:127-33

58. Makita N, Seki A, Sumitomo N, Chkourko H, Fukuhara S, Watanabe H, Shimizu W, Bezzina CR, Hasdemir C, Mugishima H, Makiyama T, Baruteau A, Baron E, Horie M, Hagiwara N, Wilde AA, Probst V, Le Marec H, Roden DM, Mochizuki N, Schott JJ, Delmar M (2012) A connexin 40 mutation associated with a malignant variant of progressive familial heart block type I. Circ Arrhythm Electrophysiol 5:163-72

59. Mathur G, Stables RH, Heaven D, Ingram A, Sutton R (2001) Permanent pacemaker implantation via the femoral vein: an alternative in cases with contraindications to the pectoral approach. Europace 3:56-59

60. McCanta AC, Schaffer MS, Collins K (2011) Pediatric and Adult Congenital Endocardial Lead Extraction or Abandonment Decision (PACELEAD) survey of lead management. Pacing Clin Electrophysiol 34:1621-27

61. McCulley DJ, Black BL (2012) Transcription factor pathways and congenital heart disease. Curr Top Dev Biol 100:253-277

62. McElhinney DB, Geiger E, Blinder J, Benson DW, Goldmuntz E (2003) NKX2.5 mutations in patients with congenital heart disease. J Am Coll Cardiol 42:1650-1655

63. McLeod KA (2010) Cardiac pacing in infants and children. Heart 96 $1502-8$

64. Michaelsson M, Riesenfeld T, Jonzon A (1997) Natural history of congenital complete atrioventricular block. Pacing Clin Electrophysiol 20:2098-2101

65. Michaëlsson M, Jonzon A, Riesenfeld T (1995) Isolated congenital complete atrioventricular block in adult life. A prospective study. Circulation 92:442-9

66. Moak JP, Barron KS, Hougen TJ, Wiles HB, Balaji S, Sreeram N, Cohen MH, Nordenberg A, Van Hare GF, Friedman RA, Perez M, Cecchin F, Schneider DS, Nehgme RA, Buyon JP (2001) Congenital heart block: development of late-onset cardiomyopathy, a previously underappreciated sequela. J Am Coll Cardiol 37:238-42

67. Moak JP, Hasbani K, Ramwell C, Freedenberg V, Berger JT, DiRusso G, Callahan P (2006) Dilated cardiomyopathy following right ventricular pacing for $\mathrm{AV}$ block in young patients: resolution after upgrading to biventricular pacing systems. J Cardiovasc Electrophysiol 17:1068-1071 
68. Modi N, Lewis H, Al-Naqeeb N, Ajayi-Obe M, Dore CJ, Rutherford M (2001) The effects of repeated antenatal glucocorticoid therapy on the developing brain. Pediatr Res 50:581-5

69. Mosquera VX, Marini M, Portela F, Cao I (2008) Late complication of classic Fontan operation: giant right atrial thrombus and massive pulmonary thromboembolism. J Card Surg 23:776-778

70. Priori SG, Wilde AA, Horie M, Cho Y, Behr ER, Berul C, Blom N, Brugada J, Chiang CE, Huikuri H, Kannankeril P, Krahn A, Leenhardt A, Moss A, Schwartz PJ, Shimizu W, Tomaselli G, Tracy C (2013) HRS/EHRA/APHRS expert consensus statement on the diagnosis and management of patients with inherited primary arrhythmia syndromes. Heart Rhythm 10:1932-1963

71. Reddy VY, Knops RE, Sperzel J, Miller MA, Petru J, Simon J, Sediva L, de Groot JR, Tjong FV, Jacobson P, Ostrosff A, Dukkipati SR, Koruth JS, Wilde AA, Kautzner J, Neuzil P (2014) Permanent leadless cardiac pacing: results of the LEADLESS trial. Circulation 129:1466-71

72. Rein AJ, Mevorach D, Perles Z, Gavri S, Nadjari M, Nir A, Elchalal U (2009) Early diagnosis and treatment of atrioventricular block in the fetus exposed to maternal anti-SSA/Ro-SSB/La antibodies: a prospective, observational, fetal kinetocardiogram-based study. Circulation 119:1867-72

73. Robledo-Nolasco R, Ortiz-Avalos M, Rodriguez-Diez G, JimenezCarrillo C, Ramírez-Machuca J, De Haro S, Castro-Villacorta H (2009) Transvenous pacing in children weighing less than 10 kilograms. Pacing Clin Electrophysiol 32:S177-81

74. Rosen MR (2014) Gene therapy and biological pacing. N Engl J Med 371:1158-9

75. Ruffatti A, Milanesi O, Chiandetti L, Cerutti A, Gervasi MT, De Silvestro G, Pengo V, Punzi L (2012) A combination therapy to treat second-degree anti-Ro/La-related congenital heart block: a strategy to avoid stable third-degree heart block? Lupus 21: $666-71$

76. Schmidt KG, Ulmer HE, Silverman NH, Kleinman CS, Copel JA (1991) Perinatal outcome of fetal complete atrioventricular block: a multicenter experience. J Am Coll Cardiol 17:1360-6

77. Schott JJ, Alshinawi C, Kyndt F, Probst V, Hoorntje TM, Hulsbeek M, Wilde AA, Escande D, Mannens MM, Le Marec H (1999) Cardiac conduction defects associate with mutations in SCN5A. Nat Genet 23:20-21

78. Schott JJ, Benson DW, Basson CT, Pease W, Silberbach GM, Moak JP, Maron BJ, Seidman CE, Seidman JG (1998) Congenital heart disease caused by mutations in the transcription factor NKX2-5. Science 281:108-111

79. Silvetti MS, Drago F, Di Carlo D, Placidi S, Brancaccio G, Carotti A (2013) Cardiac pacing in paediatric patients with congenital heart defects: transvenous or epicardial? Europace 15:1280-6

80. Silvetti MS, Drago F, Marcora S, Ravà L (2007) Outcome of singlechamber, ventricular pacemakers with transvenous leads implanted in children. Europace 9:894-9

81. Silvetti MS, Di Carlo D, Ammirati A, Placidi S, Di Mambro C, Ravà L, Drago F (2015) Left ventricular pacing in neonates and infants with isolated congenital complete or advanced atrioventricular block: short- and medium-term outcome. Europace 17:603-10

82. Sperzel J, Burri H, Gras D, Tjong FV, Knops RE, Hindricks G, Steinwender C, Defaye P (2015) State of the art of leadless pacing. Europace 17:1508-13

83. Spotnitz HM (1990) Transvenous pacing in infants and children with congenital heart disease. Ann Thorac Surg 49:495-6

84. Stephenson EA, Casavant D, Tuzi J, Alexander ME, Law I, Serwer G, Strieper M, Walsh EP, Berul CI, ATTEST Investigators (2003) Efficacy of atrial antitachycardia pacing using the Medtronic AT500 pacemaker in patients with congenital heart disease. Am J Cardiol 92:871-876
85. Stojanov PL, Savic DV, Zivkovic MB, Calovic ZR (2008) Permanent endovenous pediatric pacing: absence of lead failure-20 years follow-up study. Pacing Clin Electrophysiol 31: $1100-7$

86. Sweeney MO, Hellkamp AS, Ellenbogen KA, Greenspon AJ, Freedman RA, Lee KL, Lamas GA, MOde Selection Trial Investigators, (2003) Adverse effect of ventricular pacing on heart failure and atrial fibrillation among patients with normal baseline QRS duration in a clinical trial of pacemaker therapy for sinus node dysfunction. Circulation 107:2932-2937

87. Takahashi K, Cecchin F, Fortescue E, Berul CI, Alexander ME, Walsh EP, Fynn-Thompson F, Triedman JK (2009) Permanent atrial pacing lead implant route after Fontan operation. Pacing Clin Electrophysiol 32:779-785

88. Taketazu M, Lougheed J, Yoo SJ, Lim JS, Hornberger LK (2006) Spectrum of cardiovascular disease, accuracy of diagnosis, and outcome in fetal heterotaxy syndrome. Am J Cardiol 97:720-4

89. Takeuchi D, Tomizawa Y (2013) Pacing device therapy in infants and children: a review. J Artif Organs 16:23-33

90. Taylor PV, Scott JS, Gerlis LM, Esscher E, Scott O (1986) Maternal antibodies against fetal cardiac antigens in congenital complete heart block. N Engl J Med 315:667-72

91. Thambo JB, Bordachar P, Garrigue S, Lafitte S, Sanders P, Reuter S, Girardot R, Crepin D, Reant P, Roudaut R, Jaïs P, Haïssaguerre M, Clementy J, Jimenez M (2004) Detrimental ventricular remodelling in patients with congenital complete heart block and chronic right ventricular apical pacing. Circulation 110:3766-3772

92. Tsao S, Deal BJ, Backer CL, Ward K, Franklin WH, Mavroudis C (2009) Device management of arrhythmias after Fontan conversion. J Thorac Cardiovasc Surg 138:937-940

93. Tung S, Lemaitre J (2015) His bundle pacing: in pursuit of the "sweet spot". Pacing Clin Electrophysiol 38:537-9

94. Udink ten Cate FE, Breur JM, Cohen MI, Boramanand N, Kapusta L, Crosson JE, Brenner JI, Lubbers LJ, Friedman AH, Vetter VL, Meijboom EJ (2001) Dilated cardiomyopathy in isolated congenital complete atrioventricular block: early and long-term risk in children. J Am Coll Cardiol 37:1129-1134

95. Villain E, Coastedoat-Chalumeau N, Marijon E, Boudjemline Y, Piette JC, Bonnet D (2006) Presentation and prognosis of complete atrioventricular block in childhood, according to maternal antibody status. J Am Coll Cardiol 48:1682-1687

96. Villain E (2008) Indications for pacing in patients with congenital heart disease. Pacing Clin Electrophysiol 31:S17-20

97. Warnes C (2006) Transposition of the great arteries. Circulation 114:2699-2709

98. Wilhelm BJ, Thöne M, El-Scheich T, Livert D, Angelico R, Osswald B (2015) Complications and risk assessment of 25 years in pediatric pacing. Ann Thorac Surg 100:147-53

99. Wilkoff BL, Cook JR, Epstein AE, Greene HL, Hallstrom AP, Hsia H, Kutalek SP, Sharma A, Dual Chamber and VVI Implantable Defibrillator Trial Investigators (2002) Dual-chamber pacing or ventricular backup pacing in patients with an implantable defibrillator: the dual chamber and VVI implantable defibrillator (DAVID) trial. JAMA 288:3115-3123

100. Yildirim I, Karagöz T, Ertuğrul İ, Karagöz AH, Özer S (2013) Efficacy and safety of cryoablation of parahissian accessory pathways in children: a single institution study. Pacing Clin Electrophysiol 36:1495-502

101. Zaidi S, Choi M, Wakimoto H, Ma L, Jiang J, Overton JD, RomanoAdesman A, Bjornson RD, Breitbart RE, Brown KK, Carriero NJ, Cheung YH, Deanfield J, DePalma S, Fakhro KA, Glessner J, Hakonarson H, Italia MJ, Kaltman JR, Kaski J, Kim R, Kline JK, Lee T, Leipzig J, Lopez A, Mane SM, Mitchell LE, Newburger JW, Parfenov M, Pe'er I, Porter G, Roberts AE, Sachidanandam R, Sanders SJ, Seiden HS, State MW, Subramanian S, Tikhonova IR, Wang W, Warburton D, White PS, Williams IA, Zhao H, Seidman 
JG, Brueckner M, Chung WK, Gelb BD, Goldmuntz E, Seidman CE, Lifton RP (2013) De novo mutations in histone-modifying genes in congenital heart disease. Nature 498:220-3

102. Zartner P, Christians C, Stelter JC, Hraška V, Schneider MB (2014) Transvascular closure of single and multiple muscular ventricular septal defects in neonates and infants $<20 \mathrm{~kg}$. Catheter Cardiovasc Interv 83:564-70

103. Zhao H, Cuneo BF, Strasburger JF, Huhta JC, Gotteiner NL, Wakai RT (2008) Electrophysiological characteristics of fetal atrioventricular block. J Am Coll Cardiol 51:77-84 